ophthalmic clinic for not less than six hours a week during a period of three months, and has attended a course of systematic instruction in ophthalmology, and

(2) No student shall be considered to have passed the qualifying examination unless he has shown a sound knowledge of practical ophthalmology in an examination conducted by ophthalmic surgeons.

We may remind readers that in July last the Oxford Ophthalmological Congress determined to make representations to the General Medical Congress in support of those referred to that body by the Council of British Ophthalmologists.

In spite of official discouragement we trust the subject will not be lost sight of by those interested in the welfare of the community.

\title{
Railwaymen's Sight
}

The following letters appeared in the correspondence columns of The Times too late for reproduction in the August number of this journal:

\section{EYESIGHT TESTS}

To the Editor of The Times

Sir,-I am reluctant to trouble you with a second letter on this subject, but I feel bound to point out that Mr. J. Herbert Parsons has again failed to diagnose the North-Eastern strike correctly. The alleged grievance of the strikers had reference not, as he assumes, to a colour test, but to a test for form vision - that is, a test for short sight, not for colour-blindness, for which the company have a different test altogether. Mr. Parsons reminds your readers that "people are not always satisfied when they get what they ask for ;" that may be a good reason for not giving them what they demand, but I am not clear that it affords a justification for a strike. I am, Sir, yours faithfully,

NewCaStle-upon-Tyne,

\section{A. Kaye Butterworth.} July 22.

\section{EYESIGHT TESTS \\ To the Editor of The Times}

Sir,-I had not intended to trouble you with any further communication on this subject, but Sir A. Kaye Butterworth quite misunderstands my attitude. He is naturally most concerned with his own railway, and appears to think that I hold a brief for the men. I am only concerned with the scientific principles involved, and it is merely the fact that the N.E.R. strike is attributed to eyesight tests that brings this railway into undue prominence. I may be wrong in my views, but stated briefly, they are as follows:-(1) The safety of the public and the men them. selves depends upon efficient eyesight of engine-drivers and firemen. (2) Efficient eyesight can be determined only by scientific tests applied 
by competent examiners. (3) Eyesight tests may be used by ignorant or unscrupulous persons as a subject of political propaganda. (4) Pandering to this spirit is rightly regarded by the men as a sign of weakness, and, instead of causing satisfaction, increases that attitude of suspicion to the employers which is so much to be deplored and leads to further and greater troubles.

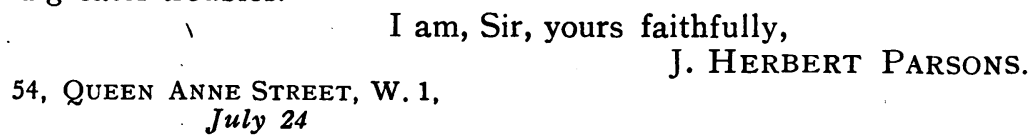

\section{Titles of Communications}

Only those whose business leads them to search ophthalmological or other scientific literature in pursuit of information about given subject can fully realize the difficulties caused by ambiguous titles. How many valuable contributions are cleverly hidden under such titles as "An interesting Case," "A Case for Diagnosis," and so forth. The writer well recalls a paper being submitted to him entitled, "Supposed death from Atropin," and the indignation with which his query was received when he asked if there was any doubt of the death having taken place. To be of service to readers a title should set forth, as briefly as may be, the contents of a communication, so that the nature of an article may be gathered at a glance. This is by no means always an easy task, but all titles that fail to fulfil the necessary conditions should be ruthlessly dealt with by the editor of the journal in which the article is to be published. On the other hand, there are authors who select lengthened titles, which in point of fact amount to an abstract of the contents of the communication they cover. This is cumbrous, although it is not so much to be condemned as the fault first mentioned. In fact, the briefer the title, consistent with lucidity, the better. The last fault is the omission of a title, throwing the onus of selecting one upon somebody else.

\section{ABSTRACTS}

\section{I.-SYMPATHETIC OPHTHALMITIS}

(I) Carpenter, E. R.-Some points relative to enucleation of the eyeball and sympathetic inflammation. Med. Press and Circular, November 2I, I9I7.

(I) Carpenter believes that the more conservative methods of dealing with injured eyes would in many cases be justified since the 